\title{
Beneficiation of oil shale by froth flotation
}

\author{
Lijun Liu ${ }^{1}$ - Gan Cheng ${ }^{2,3,4} \cdot$ Wei Yu ${ }^{1}$. Zhen $\mathrm{Li}^{1} \cdot$ Zhiyuan Yang ${ }^{1}$
}

Received: 6 March 2018 / Accepted: 4 July 2018 / Published online: 21 July 2018

(c) The Author(s) 2018

\begin{abstract}
In the future, oil shale will be an important energy resource. Froth flotation is a new method increasing the usability of oil shale. In this paper, oil shale samples were characterized based on their mineral composition, proximate analysis, ultimate analysis, size distribution, and density analysis. In addition, the flotation performance of oil shale was investigated. The effects of pulp concentration, agitation speed, aeration rate, and the type of reagents on the flotation performance were explored. Analysis of the samples' characteristics indicates that cleansed oil shale is highly usable. The optimal flotation performance occurred for a pulp concentration of $50 \mathrm{~g} / \mathrm{L}$, a collector dosage of $1000 \mathrm{~g} / \mathrm{t}$, a frother dosage of $300 \mathrm{~g} / \mathrm{t}$, an agitation speed of $1900 \mathrm{rpm}$, and an aeration rate of $160 \mathrm{~L} / \mathrm{h}$. Froth flotation is a mature method and is widely used, and thus, it can be used to improve the industrial production of oil shale.
\end{abstract}

Keywords Oil shale $\cdot$ Flotation $\cdot$ Ash $\cdot$ Recovery $\cdot$ Production

\section{Introduction}

Coal, oil, and natural gas are the three main energy sources used worldwide, and they provide a sound foundation for economic and social development (Olajossy 2017). However, these fossil fuel energy resources are non-renewable and will eventually be exhausted. Therefore, it is becoming necessary to develop non-conventional energy sources (Yu et al. 2016). Oil shale can be pyrolyzed to produce an alternative petroleum fuel called shale oil in significant amounts. Oil shale is a sedimentary rock containing abundant organic matter. Oil shale resources are rich and are primarily located in the United States, China, Russia, Brazil, Morocco, Jordan, Australia, Estonia, and Canada. In China, more than $85 \%$ of the oil shale resources are located in Jilin, Liaoning, and

Gan Cheng

chenggan464@126.com

1 School of Chemistry and Chemical Engineering, Xi' an University of Science and Technology, Xi' an 710054, China

2 Synergism Innovative Center of Coal Safety Production in Henan Province, Henan Polytechnic University, Jiaozuo 454000, China

3 College of Chemistry and Chemical Engineering, Henan Polytechnic University, Jiaozuo 454000, China

4 Henan Key Laboratory of Coal Green Transformation, Henan Polytechnic University, Jiaozuo 454000, China
Guangdong provinces. The oil shale reserves in Liaoning Province account for $11.6 \%$ of the total reserves in China. In 2014, global oil shale production increased to approximately $140 \times 10^{4} \mathrm{t}$, including $78 \times 10^{4} \mathrm{t}$ produced in China, $50 \times 10^{4}$ $\mathrm{t}$ produced in Estonia, and $18 \times 10^{4} \mathrm{t}$ produced in Brazil (Pan et al. 2016). At present, oil shale is mainly used in pyrolysis and generating electricity, and many countries have identified development of oil shale resources as an important project.

The main components of oil shale waste are quartz, clay, and other minerals, which have a high surface adsorption activity and can be used for preparing environmental adsorbents and flocculants. Ash residue can be used to make ceramics, cement, other building materials, and agricultural fertilizers. The commercialized technologies for oil shale pyrolysis are mainly based on internally heating the shale by introducing either a gas heat carrier or a solid heat carrier into the retort (pyrolyzer) (Lai et al. 2017). The dry distilled gas of the oil shale can be used for cities, industrial projects, etc. A significant amount of inorganic minerals is produced when oil shale is mined, leading to a decrease in the grade and yield of the oil shale, and to an increase in the cost of the pyrolysis stage of production. These factors make oil shale energy less readily usable.

Flotation has been widely used in mineral separation, oil-water separation, paper pulp de-inking, and wastewater treatment (Cheng et al. 2016). Previous studies indicate that 
Table 1 Equipment details

\begin{tabular}{lll}
\hline Equipment & Producer & Model \\
\hline Flotation machine & Jilin Prospecting Machinery Factory & XFD $_{\text {IV }}-1.5 \mathrm{~L}$ \\
Vacuum filter & Wuhan Rock Crush \& Grand Equipment Manufac- & RK/ZL-ø260/ø200 \\
& ture Co., Ltd & \\
Thermostatic drying oven & Tianjin Taisite Instrument Co., Ltd & $101-3 \mathrm{AB}$ \\
Muffle furnace & Test Center of China Coal Research Institute & GW 300C \\
\hline
\end{tabular}

flotation is inexpensive, it reduces the amount of mineral ash, and it enriches the material in useful minerals (Tsai and Lumpkin 1984; Cheng et al. 2017). However, until now, only a few articles have concentrated on oil-shale flotation. Thyabat et al. (2014) thought that flotation could improve the grade of low-grade oil shale. Altun et al. (2009) used ultrasonically aided flotation to improve the floatability of oil shale and concluded that the particulates filling the pores/voids or attached to the surfaces of the larger particles were effectively removed after ultrasonic treatment. $\mathrm{Li}$ et al. (2012) studied the effect of the dosages of the oleic acid collector, the kerosene collector, and the frother on the floatability of Fushun oil shale. Their results indicate that oleic acid and kerosene collectors affect the enrichment of organic matter in the oil shale. Altun et al. (2006a, b) investigated the effects of the conditioning time, flotation time, pulp density, particle size, and the frother dosage on the flotation performance of the Himmetoğlu oil shale. Their factorial experiments showed that pulp density was the most important parameter affecting flotation performance. The FTIR spectrum confirmed the organic-rich and highly humic character of oil shale. El-Mofty (2018) obtained a $20 \%$ kerogen concentrate from a $10 \%$ kerogen sample with $70 \%$ recovery at a $\mathrm{pH}$ of 5 without a collector.

Although flotation is an effective method for increasing the grade of an oil shale, flotation has not been extensively investigated in previous studies. Although the parameters affecting flotation are complex, this paper investigates them to optimize the flotation process. In addition, the characteristics of oil shale are analyzed to explain the observed flotation phenomena.

\section{Experiment}

\section{Materials and instruments}

The oil shale sample described in this paper was collected from Sichuan Province, China. The sample was crushed to $<500 \mu \mathrm{m}$ and was mixed uniformly for chemical analysis. A flotation study was performed in a conventional mechanical flotation cell. Kerosene and octanol were used as the collector and frother, respectively. The details of the equipment used in this study are given in Table 1.
Table 2 Ultimate analysis results

\begin{tabular}{lccccc}
\hline Element & $\mathrm{C}_{\mathrm{ad}}$ & $\mathrm{H}_{\mathrm{ad}}$ & $\mathrm{O}_{\mathrm{ad}}$ & $\mathrm{N}_{\mathrm{ad}}$ & $\mathrm{S}_{\mathrm{ad}}$ \\
\hline Content $(\%)$ & 43.6 & 4.04 & 15 & 0.68 & 0.1 \\
\hline
\end{tabular}

Table 3 Proximate analysis results

\begin{tabular}{lllll}
\hline Composition & Moisture & Ash & Volatiles & Fixed carbon \\
\hline Proportion (\%) & 0.15 & 28.25 & 45.82 & 25.23 \\
\hline
\end{tabular}

\section{Characteristic analysis}

The mineral composition of the sample was analyzed using $\mathrm{X}$-ray diffraction. The sample was determined to be primarily composed of quartz $\left(\mathrm{SiO}_{2}\right)$, dolomite $\left[\mathrm{CaMg}\left(\mathrm{CO}_{3}\right)_{2}\right]$, and oblique calcium zeolite $\left(\mathrm{CaAl}_{2} \mathrm{Si}_{2} \mathrm{O}_{8} \cdot 4 \mathrm{H}_{2} \mathrm{O}\right)$.

As shown in Table 2, the carbon contents are $43.6 \%$, indicating that organic matter is abundant in this oil shale. The ratio of carbon atoms to hydrogen atoms is 9:10, which is close to that of aromatic hydrocarbons, indicating that the oil shale contains many benzene rings (Xue et al. 2009). The sulfur content is low, indicating that the oil shale does not need to be desulfurated and that only ash needs to be removed.

As shown in Table 3, the volatile content is $45.82 \%$ and the ash content is $28.25 \%$. Generally, a high volatile content and a low ash content indicate a high oil concentration. Therefore, this oil shale is highly usable.

Table 4 shows that the ash content of the sample increases slightly with decreasing particle size. In particular, the ash content sharply increases at $75 \mu \mathrm{m}$. The yield of the $<45 \mu \mathrm{m}$ particle size is $18.40 \%$. The $250-75 \mu \mathrm{m}$ size particles account for $55.28 \%$ of the total mass of the sample.

Table 5 indicates that the yield of the $<1.30 \mathrm{~g} / \mathrm{cm}^{3}$ particles is $18.23 \%$, and they have an ash content of $22.39 \%$. The yield of the medium density $\left(1.40-1.60 \mathrm{~g} / \mathrm{cm}^{3}\right)$ particles is $22.51 \%$, and they have an ash content of $24.94 \%$. This result indicates the existence of several mineral combinations. The yield of the $>1.60 \mathrm{~g} / \mathrm{cm}^{3}$ density particles is relatively low. Particles with densities of $1.3-1.4 \mathrm{~g} / \mathrm{cm}^{3}$ account for $44.48 \%$ of the total mass of the sample. 
Table 4 Size distribution

\begin{tabular}{lllll}
\hline Size $(\mu \mathrm{m})$ & Wt\% & Ash $(\%)$ & \multicolumn{2}{c}{ Cumulative oversize } \\
\cline { 3 - 5 } & & & Wt\% & Ash $(\%)$ \\
\hline$>500$ & 1.54 & 25.03 & 1.54 & 25.03 \\
$500-250$ & 16.32 & 26.61 & 17.86 & 26.47 \\
$250-125$ & 32.65 & 26.55 & 50.51 & 26.52 \\
$125-75$ & 22.63 & 28.55 & 73.14 & 27.15 \\
$75-45$ & 8.47 & 31.82 & 81.6 & 27.63 \\
$<45$ & 18.4 & 37.56 & 100 & 29.46 \\
Totals & 100 & 29.46 & - & - \\
\hline
\end{tabular}

\section{Analytical methods}

The main factors affecting the flotation of oil shale were studied using a single-factor experiment, e.g., pulp concentration, reagent dosage, aeration rate, and agitation speed. The experimental flowchart is shown in Fig. 1.

In this paper, the ash reduction ratio, combustible recovery, and flotation perfect index are adopted to evaluate and compare the flotation effects. These factors are defined as follows:

1. The ash reduction ratio $\left(A_{\mathrm{R}}\right)$ refers to the percentage of ash reduction of the raw oil shale ash, and it measures the ability of the process to remove ash.

$A_{\mathrm{R}}=\frac{A_{f}-A_{\mathrm{c}}}{A_{f}} \times 100 \%$,

where $A_{\mathrm{c}}$ is the ash concentration $(\mathrm{Wt} \%), A_{f}$ is the ash content of the raw oil shale (Wt\%), and $A_{\mathrm{t}}$ is the ash content of the tailings (Wt\%).

2. The combustible recovery $(\varepsilon)$ refers to the percentage of the combustible material per the amount of raw oil shale where combustible material refers to the non-ash materials.

$\varepsilon=\frac{A_{\mathrm{t}}-A_{f}}{A_{\mathrm{t}}-A_{\mathrm{c}}} \times \frac{100-A_{\mathrm{c}}}{100-A_{f}} \times 100 \%$

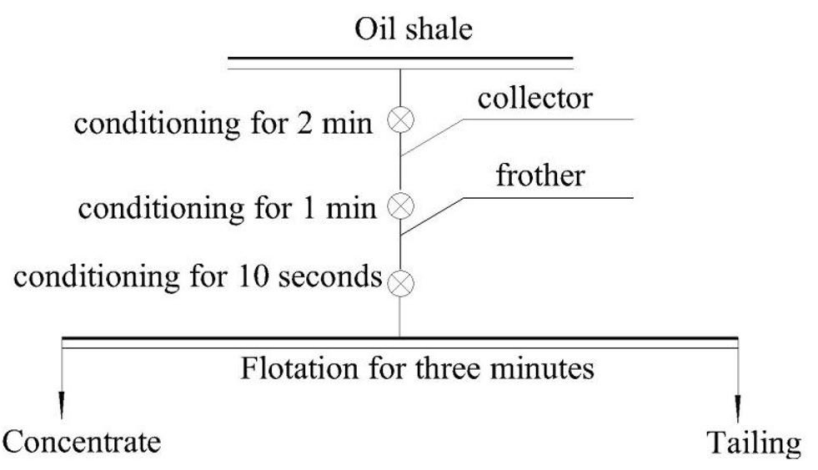

Fig. 1 Flotation experiment flowchart

3. The flotation perfect index $(\eta)$ is an overall indicator. The higher the flotation perfect index, the better the flotation effect (Xie 2001).

$$
\eta=\frac{A_{\mathrm{t}}-A_{f}}{A_{\mathrm{t}}-A_{\mathrm{c}}} \times \frac{A_{f}-A_{\mathrm{c}}}{A_{f}\left(100-A_{f}\right)} \times 100 \%
$$

\section{Results and discussion}

\section{Pulp concentration}

The pulp concentration experimental parameters used for the raw oil shale are as follows: an agitation speed of $1900 \mathrm{rpm}$ (revolutions per minute); an aeration rate of $160 \mathrm{~L} / \mathrm{h}$; a collector dosage of $1000 \mathrm{~g} / \mathrm{t}$; and a frother dosage of $300 \mathrm{~g} / \mathrm{t}$. The concentrations used were $30,50,70,90$, and $110 \mathrm{~g} / \mathrm{L}$, and all of the results are shown in Table 6 .

As can be seen from Table 6, as the concentration increases, the concentrate yield initially increases, and then, it slowly decreases. Whereas, the ash content of the concentrate gradually increases. When the concentration is, the yield reaches its maximum (90.34\%) at a concentration of $90 \mathrm{~g} / \mathrm{L}$; while the ash content reaches its minimum (20.88\%) at a concentration of $30 \mathrm{~g} / \mathrm{L}$. The ash reduction ratio gradually decreases with increasing concentration, and its maximum is $22.95 \%$. The combustible recovery reaches its
Table 5 Density distribution

\begin{tabular}{|c|c|c|c|c|c|c|}
\hline \multirow{2}{*}{$\begin{array}{l}\text { Specific gravity frac- } \\
\text { tion }\left(\mathrm{g} / \mathrm{cm}^{3}\right)\end{array}$} & \multirow[t]{2}{*}{$\mathrm{Wt} \%$} & \multirow[t]{2}{*}{ Ash (\%) } & \multicolumn{2}{|c|}{ Cumulative floats } & \multicolumn{2}{|c|}{ Cumulative sinks } \\
\hline & & & $\mathrm{Wt} \%$ & Ash (\%) & $\mathrm{Wt} \%$ & Ash (\%) \\
\hline$<1.3$ & 18.23 & 22.39 & 18.23 & 22.39 & 100.00 & 30.11 \\
\hline $1.4-1.3$ & 44.48 & 23.00 & 62.71 & 22.82 & 81.77 & 31.84 \\
\hline $1.5-1.4$ & 15.24 & 22.55 & 77.95 & 22.77 & 37.29 & 42.38 \\
\hline $1.6-1.5$ & 7.27 & 29.96 & 85.23 & 23.38 & 22.05 & 56.08 \\
\hline $1.7-1.6$ & 8.90 & 57.51 & 94.13 & 26.61 & 14.77 & 68.94 \\
\hline $1.8-1.7$ & 2.70 & 79.67 & 96.83 & 28.09 & 5.87 & 86.27 \\
\hline$>1.8$ & 3.17 & 91.89 & 100.00 & 30.11 & 3.17 & 91.89 \\
\hline Totals & 100.0 & 30.11 & - & - & & \\
\hline
\end{tabular}


Table 6 Concentration experiment data

\begin{tabular}{|c|c|c|c|c|c|c|c|}
\hline \multirow{2}{*}{$\begin{array}{l}\text { Concentra- } \\
\text { tion }(g / L)\end{array}$} & \multicolumn{2}{|c|}{ Concentrate (\%) } & \multicolumn{2}{|c|}{ Tailings (\%) } & \multirow{2}{*}{$\begin{array}{l}\text { Ratio of ash } \\
\text { reduction }(\%)\end{array}$} & \multirow{2}{*}{$\begin{array}{l}\text { Combustible } \\
\text { recovery }(\%)\end{array}$} & \multirow[t]{2}{*}{ Perfect index $(\%)$} \\
\hline & Yield & Ash & Yield & Ash & & & \\
\hline 30 & 81.00 & 20.88 & 19.00 & 53.60 & 22.95 & 87.91 & 25.49 \\
\hline 50 & 89.24 & 21.04 & 10.76 & 76.36 & 22.05 & 96.52 & 26.95 \\
\hline 70 & 89.45 & 21.42 & 10.55 & 77.11 & 21.52 & 96.68 & 26.48 \\
\hline 90 & 90.34 & 21.28 & 9.66 & 77.92 & 20.45 & 97.09 & 25.22 \\
\hline 110 & 89.84 & 22.83 & 10.16 & 79.71 & 20.20 & 97.11 & 25.42 \\
\hline
\end{tabular}

maximum at a concentration of $110 \mathrm{~g} / \mathrm{L}$. The perfect index reaches its maximum, at an ash reduction ratio of $22.05 \%$ a concentration of $50 \mathrm{~g} / \mathrm{L}$, and a combustible recovery of $96.52 \%$.

The above described results are due to the following: (1) When the pulp concentration increases, the fine particles in the pulp coat the coarse particles, affecting the separation process and the concentrate's quality. (2) It is easy for the fine particles in the pulp to adsorb the agent, so the amount of pulp agent decreases, affecting the bubble-particle interaction. (3) When the fine particle content of the slurry is high, the viscosity of the pulp increases, which affects the aeration process and makes it difficult to form uniform and stable bubbles. (4) When the pulp concentration increases, the solid particle content increases, the uniformity of the bubble distribution will be affected, and the interference between the ore and mineral particles and the mineralized bubbles will increase, which will affect the concentrate's quality. Therefore, $80 \mathrm{~g} / \mathrm{L}$ is the optimal concentration.

\section{Agitation speed}

The agitation speed directly affects the mixing strength of the pulp, aeration rate, bubble size, etc. Thus, it is necessary to study the agitation speed. The pulp concentration was maintained at $50 \mathrm{~g} / \mathrm{L}$, the aeration rate at $160 \mathrm{~L} / \mathrm{h}$, the collector concentration at $1000 \mathrm{~g} / \mathrm{t}$, and the frother concentration at $300 \mathrm{~g} / \mathrm{t}$. The agitation speed was tested at 1500 , 1700, 1900, 2100, and $2300 \mathrm{rpm}$. The experimental results are shown in Table 7.

As can be seen from Table 7, when the agitation speed increases, the concentrate yield initially decreases, and then, it increases, while the amount of ash and the recovery rate of the concentrate increases. The maximum yield was $90.42 \%$, and the minimum ash concentration was $20.39 \%$. The perfect index reached its maximum $(27.09 \%)$ at an agitation speed of $1900 \mathrm{rpm}$. Therefore, $1900 \mathrm{rpm}$ was selected as the optimal impeller speed.

\section{Aeration rate}

The experimental conditions used were as follows: a pulp concentration of $50 \mathrm{~g} / \mathrm{L}$, an agitation speed of $1900 \mathrm{rpm}$, a collector concentration of $1000 \mathrm{~g} / \mathrm{t}$, and a frother concentration of $300 \mathrm{~g} / \mathrm{t}$. The aeration rates tested were 160, 240, 320 , and $400 \mathrm{~L} / \mathrm{h}$, and the experimental results are shown in Table 8.

As can be seen from Table 8 , as the aeration rate increases, the concentrate yield initially increases, and then, it decreases. The maximum yield was $89.22 \%$, and the minimum ash concentration was $21.55 \%$. The perfect index reached its maximum $(28.01 \%)$ at an aeration rate of $160 \mathrm{~L} / \mathrm{h}$. Therefore, $160 \mathrm{~L} / \mathrm{h}$ was selected as the optimal aeration rate.

\section{Reagents}

The collector and frother experiments were conducted separately (Gupta 2017). The experimental conditions used were as follows: a pulp concentration of $50 \mathrm{~g} / \mathrm{L}$, an agitation speed of $1900 \mathrm{rpm}$, an aeration rate of $160 \mathrm{~L} / \mathrm{h}$ and a frother concentration of $300 \mathrm{~g} / \mathrm{t}$. The kerosene dosages tested were at 200, 600, 1000, 1400, and $1800 \mathrm{~g} / \mathrm{t}$. The collector experiment results are listed in Table 9.

Table 9 shows that the maximal yield was $89.85 \%$, and the minimal ash concentration was $21.24 \%$. The perfect
Table 7 Influence of agitation speed on flotation

\begin{tabular}{|c|c|c|c|c|c|c|c|}
\hline \multirow{2}{*}{$\begin{array}{l}\text { Agitation } \\
\text { speed (rpm) }\end{array}$} & \multicolumn{2}{|c|}{ Concentrate $(\%)$} & \multicolumn{2}{|c|}{ Tailings (\%) } & \multirow{2}{*}{$\begin{array}{l}\text { Ash reduction } \\
\text { ratio }(\%)\end{array}$} & \multirow{2}{*}{$\begin{array}{l}\text { Combustible } \\
\text { recovery }(\%)\end{array}$} & \multirow[t]{2}{*}{ Perfect index (\%) } \\
\hline & Yield & Ash & Yield & Ash & & & \\
\hline 1500 & 89.88 & 20.39 & 10.12 & 71.60 & 20.26 & 96.14 & 24.47 \\
\hline 1700 & 89.10 & 20.67 & 10.90 & 74.37 & 22.07 & 96.20 & 26.77 \\
\hline 1900 & 89.03 & 21.12 & 10.97 & 75.97 & 22.17 & 96.38 & 27.09 \\
\hline 2100 & 90.29 & 21.47 & 9.71 & 74.79 & 19.43 & 96.66 & 23.92 \\
\hline 2300 & 90.42 & 22.19 & 9.58 & 77.09 & 19.16 & 96.98 & 23.88 \\
\hline
\end{tabular}

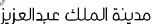

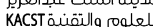


index reached its maximum (27.65\%) at a kerosene dosage of $1000 \mathrm{~g} / \mathrm{t}$. Therefore, $1000 \mathrm{~g} / \mathrm{t}$ was selected as the optimal kerosene dosage.

The kerosene dosages was maintained at $1000 \mathrm{~g} / \mathrm{t}$, while different octanol dosages were tested. The frother experiment results are shown in Table 10.

Table 10 shows that the perfect index reached its maximum $(27.24 \%)$ at an octanol dosage of $300 \mathrm{~g} / \mathrm{t}$. Therefore, $300 \mathrm{~g} / \mathrm{t}$ was selected as the optimal kerosene dosage.

In summary, the optimal reagent dosages were $1000 \mathrm{~g} / \mathrm{t}$ for the collector and $300 \mathrm{~g} / \mathrm{t}$ for the frother.

\section{Conclusions}

Oil shale is potential alternative energy resource. Thus, methods of improving the grade of oil shale are of great interest. In this paper, the flotation method was adopted and its optimal conditions were determined. Characteristic analysis indicates that the oil shale studied is highly usable, and therefore, that the flotation method can be applied to improve the usability of oil shale.
1. In this study, oil shale samples were characterized based on mineral composition, elemental composition, industrial analysis, size composition, and density composition. The results indicate that the samples are primarily composed of quartz $\left(\mathrm{SiO}_{2}\right)$, dolomite $\left[\mathrm{CaMg}\left(\mathrm{CO}_{3}\right)_{2}\right]$, and oblique calcium zeolite $\left(\mathrm{CaAl}_{2} \mathrm{Si}_{2} \mathrm{O}_{8} \cdot 4 \mathrm{H}_{2} \mathrm{O}\right)$. The carbon content is $43.6 \%$, indicating that organic matter is abundant in the oil shale. From the 250 to $75 \mu \mathrm{m}$ particles account for $55.28 \%$ of the total mass of the sample. Particles with densities ranging from 1.4 to $1.3 \mathrm{~g} / \mathrm{cm}^{3}$ account for $44.48 \%$ of the total mass of the sample.

2. The flotation performance of the oil shale was also investigated. The effects of pulp concentration, agitation speed, aeration rate, and the type of reagent on the cleaning performance were explored. The characteristic analysis indicates that the following parameter values are used for the flotation process: a pulp concentration of $50 \mathrm{~g} / \mathrm{L}$, a collector concentration of $1000 \mathrm{~g} / \mathrm{t}$, a frother concentration of $300 \mathrm{~g} / \mathrm{t}$, an agitation speed of $1900 \mathrm{rpm}$, and an aeration rate of $160 \mathrm{~L} / \mathrm{h}$. Because the flotation method is mature and is widely used, flotation can be easily applied by industrial operations.
Table 8 Influence of aeration rate on flotation

Table 9 Collector experiment data

Table 10 Frother experiment data

\begin{tabular}{|c|c|c|c|c|c|c|c|}
\hline \multirow{2}{*}{$\begin{array}{l}\text { Aeration } \\
\text { rate }(\mathrm{L} / \mathrm{h})\end{array}$} & \multicolumn{2}{|c|}{ Concentrate $(\%)$} & \multicolumn{2}{|c|}{ Tailings (\%) } & \multirow{2}{*}{$\begin{array}{l}\text { Ash reduction } \\
\text { ratio }(\%)\end{array}$} & \multirow{2}{*}{$\begin{array}{l}\text { Combustible } \\
\text { recovery (\%) }\end{array}$} & \multirow[t]{2}{*}{ Perfect index (\%) } \\
\hline & Yield & Ash & Yield & Ash & & & \\
\hline 160 & 89.19 & 21.55 & 10.81 & 79.93 & 22.65 & 96.99 & 28.01 \\
\hline 240 & 89.22 & 21.68 & 10.78 & 76.31 & 21.36 & 96.48 & 26.31 \\
\hline 320 & 89.13 & 21.8 & 10.87 & 73.65 & 20.55 & 96.05 & 25.24 \\
\hline 400 & 88.74 & 21.75 & 11.26 & 72.69 & 20.87 & 95.76 & 25.54 \\
\hline 480 & 87.47 & 21.72 & 12.53 & 70.22 & 21.86 & 94.83 & 26.48 \\
\hline
\end{tabular}

\begin{tabular}{|c|c|c|c|c|c|c|c|c|}
\hline \multicolumn{2}{|c|}{ Reagent dosage $(\mathrm{g} / \mathrm{t})$} & \multicolumn{2}{|c|}{$\begin{array}{l}\text { Concentrate } \\
(\%)\end{array}$} & \multicolumn{2}{|c|}{ Tailings (\%) } & \multirow{2}{*}{$\begin{array}{l}\text { Ash reduc- } \\
\text { tion ratio } \\
(\%)\end{array}$} & \multirow[t]{2}{*}{$\begin{array}{l}\text { Combustible } \\
\text { recovery }(\%)\end{array}$} & \multirow[t]{2}{*}{ Perfect index (\%) } \\
\hline Kerosene & Octanol & Yield & Ash & Yield & Ash & & & \\
\hline 200 & 300 & 87.80 & 21.88 & 12.20 & 72.45 & 22.00 & 95.33 & 26.85 \\
\hline 600 & 300 & 88.41 & 21.80 & 11.59 & 73.00 & 21.40 & 95.67 & 26.18 \\
\hline 1000 & 300 & 88.01 & 21.69 & 11.99 & 74.54 & 22.61 & 95.76 & 27.65 \\
\hline 1400 & 300 & 89.85 & 21.36 & 10.15 & 74.77 & 20.24 & 96.50 & 24.84 \\
\hline 1800 & 300 & 89.27 & 21.24 & 10.73 & 76.01 & 21.67 & 96.47 & 26.54 \\
\hline
\end{tabular}

\begin{tabular}{|c|c|c|c|c|c|c|c|}
\hline \multirow[t]{2}{*}{ Octanol (g/t) } & \multicolumn{2}{|c|}{ Concentrate $(\%)$} & \multicolumn{2}{|c|}{ Tailings (\%) } & \multirow{2}{*}{$\begin{array}{l}\text { Ash reduction } \\
\text { ratio }(\%)\end{array}$} & \multirow{2}{*}{$\begin{array}{l}\text { Combustible } \\
\text { recovery (\%) }\end{array}$} & \multirow[t]{2}{*}{ Perfect index (\%) } \\
\hline & Yield & Ash & Yield & Ash & & & \\
\hline 300 & 86.56 & 21.90 & 13.44 & 69.39 & 22.57 & 94.26 & 27.24 \\
\hline 400 & 86.30 & 22.94 & 13.70 & 66.58 & 20.68 & 93.56 & 25.11 \\
\hline 500 & 86.84 & 22.67 & 13.16 & 69.42 & 21.35 & 94.35 & 26.04 \\
\hline 600 & 85.96 & 22.00 & 14.04 & 63.04 & 20.76 & 92.82 & 24.70 \\
\hline 700 & 83.57 & 22.49 & 16.43 & 54.09 & 18.75 & 89.57 & 21.67 \\
\hline
\end{tabular}


3. Although froth flotation is an effective method of increasing the grade of an oil shale, it is controlled by variable parameters related to the ore's characteristics and by a number of operational variables. Further research needs to be conducted before oil shale can be processed on an industrial scale.

Acknowledgements Thanks for the support from "National Natural Science Foundation of China" (Grant No. 51304157).

Open Access This article is distributed under the terms of the Creative Commons Attribution 4.0 International License (http://creativeco mmons.org/licenses/by/4.0/), which permits unrestricted use, distribution, and reproduction in any medium, provided you give appropriate credit to the original author(s) and the source, provide a link to the Creative Commons license, and indicate if changes were made.

\section{References}

Altun EN, Hicyilmaz C, Hwang JY, Bagci AS (2006a) Beneficiation of Himmetoğlu oil shale by flotation as a solid fuel substitute. Part 1. Materials characteristics and flotation behavior. Energy Fuel 20:214-221

Altun EN, Hicyilmaz C, Hwang JY, Bagci AS (2006b) Beneficiation of Himmetoğlu oil shale by flotation as a solid fuel substitute. Part 2. Process optimization by a statistical approach. Energy Fuel 20:222-226

Altun EN, Hwang JY, Hicyilmaz C (2009) Enhancement of flotation performance of oil shale cleaning by ultrasonic treatment. Int $\mathbf{J}$ Miner Process 91:1-13

Cheng G, Shi CL, Liu JT, Yan XK (2016) Bubble-distribution measurement in a flotation column. Int J Coal Prep Util 36:241-250

Cheng G, Shi CL, Yan XK, Zhang ZJ, Xu HX, Lu Y (2017) A study of bubble-particle interaction in a column flotation process. Physicochem Probl Miner Process 53:18-33
El-Mofty SE, Khairy N, El-Kammar AM, El-Midany AA (2018) Upgrading of oil shale by flotation without collector. Nat Resour Res : $1-7$

Gupta N (2017) Evaluation of graphite depressants in a poly-metallic sulfide flotation circuit. Int J Min Sci Techno 27:285-292

Lai DG, Zhang GY, Xu GW (2017) Characterization of oil shale pyrolysis by solid heat carrier in moving bed with internals. Fuel Process Techno 158:191-198

Li Y, Lin N, Wu HX, Liu YH (2012) Study on demineralization and Kerogen enrichment of oil shale by flotation method. Non-ferr Min Metall 28:24-26

Olajossy A (2017) Some parameters of coal methane system that cause very slow release of methane from virgin coal beds (CBM). Int J Min Sci Techno 27:321-326

Pan LW, Dai FQ, Huang JN, Liu S, Li GQ (2016) Study of the effect of mineral matters on the thermal decomposition of Jimsar oil shale using TG-MS. Thermochim Acta 627-629:31-38

Thyabat SA, Zoubi EA, Alnawafleh H, Tarawneh KA (2014) Beneficiation of oil shale by froth flotation: critical review. Open Miner Process J 7:1-12

Tsai SC, Lumpkin RE (1984) Oil shale beneficiation by froth flotation. Fuel 63:435-439

Xie GY (2001) Mineral processing technology. China University of Mining and Technology, Xuzhou

Xue QH, Li SY, Wang HY, Zheng DW, Fang CH (2009) Utilization of Daqing oil shale and its pyrolysis products. Sci Techno Chem Ind 17:54-56

Yu XD, Luo ZF, Yang XL, Jiang HS, Zhou EH, Zhang B, Dong L (2016) Oil shale separation using a novel combined dry beneficiation process. Fuel 180:148-156

Publisher's Note Springer Nature remains neutral with regard to jurisdictional claims in published maps and institutional affiliations. 